\title{
STRUCTURAL DYNAMICS OF THE CREATIVE SECTOR IN THE BUCHAREST-ILFOV DEVELOPMENT REGION
}

DOI: http://dx.doi.org/10.18509/GBP.2020.48

UDC: 332.146.2:338.46]:303.72(498.11)"2000/2016"

\author{
Andreea Karina Gruia ${ }^{1,2}$ \\ Alexandra Grecu ${ }^{1,2}$ \\ Iulia Daniela Nedelcu ${ }^{1,2}$ \\ Marian Marin ${ }^{1,2}$ \\ Andrei Ducman ${ }^{1,2}$ \\ ${ }^{1}$ University of Bucharest - Faculty of Geography, Romania \\ ${ }^{2}$ University of Bucharest - Research Center for Integrated \\ Analysis and Territorial Management (CAIMT), Romania
}

\begin{abstract}
The creative economy is an important tool for revitalizing the regional and local economy. Creativity becomes the engine of social and economic change, transforming it into a new source of competitive advantage.

The research follows the spatial analysis of the dynamics of the creative sector for the most dynamic and complex regional economy in Romania, the Bucharest-Ilfov Development Region. The analysis of the spatial dynamics of the creative economies at the level of the region was made starting from an economic database at the level of the territorial administrative unit, for the economic indicator relevant for this study, the number of employees, at the level of the National Classification for the Economic Activities (NACE). The analyzed period is between 2000 and 2016. The establishment of the creative activities was done after the Government Decision no. 859 of 2014, which indicates, for this economic sector, a number of 66 codes grouped into 7 main areas. A series of cartographic models were made using the open source QGis platform and also graphic models for the selected indicator.

The obtained results highlighted the role of creative economies in the sustainable development of local economies, as well as their migration to the emerging space, along the accessibility corridors.
\end{abstract}

Keywords: creative economies, regional development, spatial patterns

\section{INTRODUCTION}

Creative industries are increasingly understood to contribute to localized innovation and dynamism.

The creative sector is among the fastest growing sectors in the global economy, studies show that the growth rate of this sector is twice as fast as the aggregate growth rate in the advanced economy [1], [2], [3]. This sector can be regarded as a social innovation, and the whole consisting of creativity, culture and knowledge is considered to be fundamental for economic and social development [4].

The creative economy becomes a driving force for the growth and sustenance of a national economy, in the context of fierce global competition, especially in developing countries [5]. It is one of the fastest growing sectors in terms of income generation and job creation $[6]$. 
Creative economy is a typical phenomenon of modern economies. The economic space of culture and creativity has been expanded, and the creative sectors, before being strictly intended, have broadened to embrace those other sectors whose culture and creativity are likely to rejuvenate, for example, design, economic segment that crosses a variety of sectors.

The profile and spatial dimension of creative activities have implications for the design and implementation of policy strategies [7], [8]

Different spatial models of the creative economy have been analyzed by geographical economists and regional researchers and their concentration has been noticed especially in metropolitan areas [9], giving the cities economic and social benefits [10], [11], [12].

\section{METHODOLOGY}

\section{Area of study}

The study aims to analyze the spatial distribution and the dynamics of the creative economy at the level of the Bucharest-Ilfov Development Region on the basis of an economic indicator - number of employees. The Bucharest-Ilfov Development Region is one of the eight development regions of Romania being made up of 9 cities, 32 communes and 91 villages. The region represents the largest industrial agglomeration of Romania, in which all the industrial branches are present.

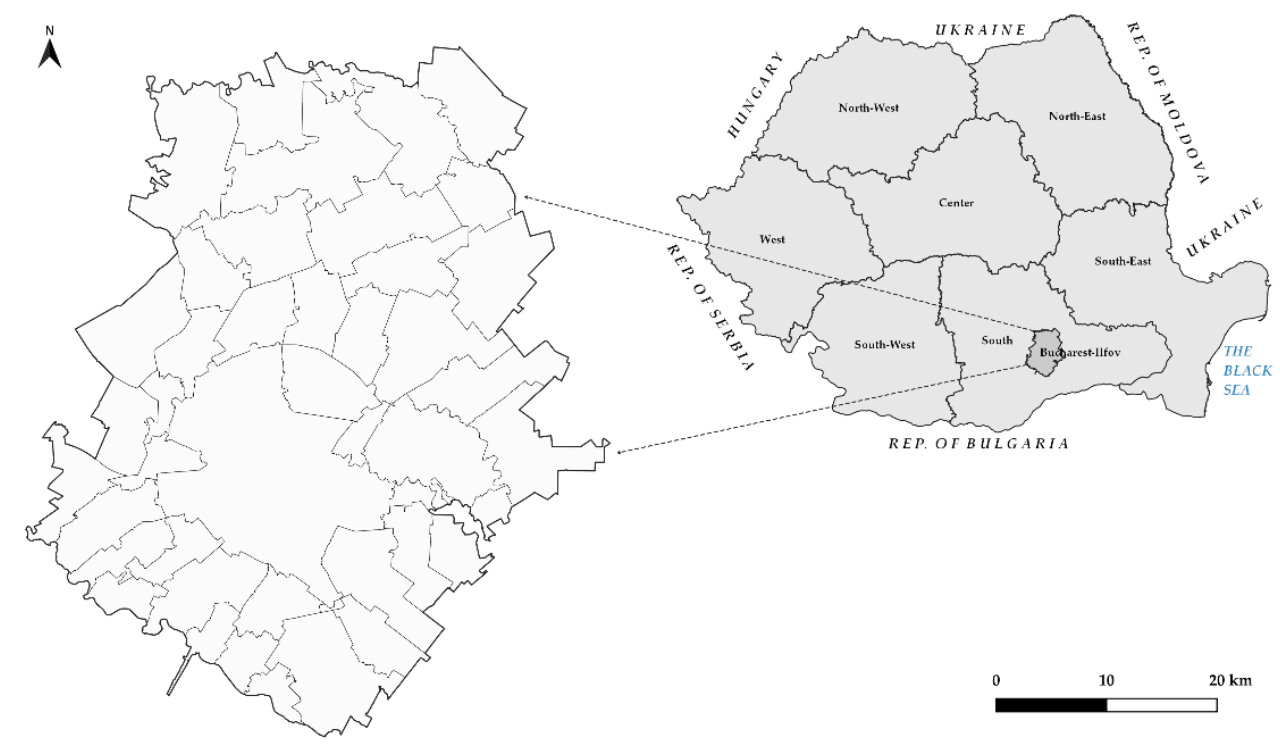

Figure 1. Location of the Bucharest-Ilfov Development Region

\section{Data analysis}

An economic database has been created at the level of administrative-territorial unit, highlighting an economic indicator relevant to the analysis of creative economies, number of employees, according to the Classification of National Economy Activities (NACE). The analysis of the economic indicator relevant to this study is between 2000 and 2016. The NACE codes belonging to the creative economies were chosen accordingly to the Government Decision no. 859 of 2014, regarding the approval of the "Government Strategy for the development of the sector of small and medium-sized enterprises and the improvement of the business environment in Romania Horizon 2020". 
Table 1. Creative areas classification

\begin{tabular}{|c|c|c|}
\hline CLASS & $\begin{array}{l}\text { NACE } \\
\text { CODES }\end{array}$ & CREATIVE ACTIVITIES \\
\hline \multirow{7}{*}{ Publishing } & 5811 & Book publishing \\
\hline & 5812 & Publishing of directories and mailing lists \\
\hline & 5813 & Publishing of newspapers \\
\hline & 5814 & Publishing of journals and periodicals \\
\hline & 5819 & Other publishing activities \\
\hline & 5821 & Publishing of computer games \\
\hline & 5829 & Other software publishing \\
\hline \multirow{13}{*}{ Media and cinema } & 5911 & Motion picture, video and television programme production activities \\
\hline & 5912 & Motion picture, video and television programme post-production activities \\
\hline & 5913 & Motion picture, video and television programme distribution activities \\
\hline & 5914 & Motion picture projection activities \\
\hline & 5920 & Sound recording and music publishing activities \\
\hline & 6391 & News agency activities \\
\hline & 7311 & Advertising agencies \\
\hline & 7312 & Media representation \\
\hline & 7320 & Market research and public opinion polling \\
\hline & 7410 & Specialised design activities \\
\hline & 7420 & Photographic activities \\
\hline & 7430 & Translation and interpretation activities \\
\hline & 7490 & Other professional, scientific and technical activities n.e.c. \\
\hline \multirow{6}{*}{ IT } & 6202 & Computer consultancy activities \\
\hline & 6203 & Computer facilities management activities \\
\hline & 6209 & Other information technology and computer service activities \\
\hline & 6311 & Data processing, hosting and related activities \\
\hline & 6312 & Web portals \\
\hline & 6399 & Other information service activities n.e.c. \\
\hline \multirow{3}{*}{$\begin{array}{l}\text { Architecture and } \\
\text { engineering }\end{array}$} & 7111 & Architectural activities \\
\hline & 7112 & Engineering activities and related technical consultancy \\
\hline & 7120 & Technical testing and analysis \\
\hline \multirow{14}{*}{$\begin{array}{c}\text { Education and } \\
\text { research }\end{array}$} & 7211 & Research and experimental development on biotechnology \\
\hline & 7219 & Other research and experimental development on natural sciences and engineering \\
\hline & 7220 & Research and experimental development on social sciences and humanities \\
\hline & 8510 & Pre-primary education \\
\hline & 8520 & Primary education \\
\hline & 8531 & General secondary education \\
\hline & 8532 & Technical and vocational secondary education \\
\hline & 8541 & Post-secondary non-tertiary education \\
\hline & 8542 & Tertiary education \\
\hline & 8551 & Sports and recreation education \\
\hline & 8552 & Cultural education \\
\hline & 8553 & Driving school activities \\
\hline & 8559 & Other education n.e.c. \\
\hline & 8560 & Educational support activities \\
\hline \multirow{9}{*}{ Health } & 8610 & Hospital activities \\
\hline & 8621 & General medical practice activities \\
\hline & 8622 & Specialist medical practice activities \\
\hline & 8623 & Dental practice activities \\
\hline & 8690 & Other human health activities \\
\hline & 8710 & Residential nursing care activities \\
\hline & 8720 & Residential care activities for mental retardation, mental health and substance abuse \\
\hline & 8730 & Residential care activities for the elderly and disabled \\
\hline & 8790 & Other residential care activities \\
\hline \multirow{14}{*}{$\begin{array}{l}\text { Culture and } \\
\text { recreation }\end{array}$} & 9001 & Performing arts \\
\hline & 9002 & Support activities to performing arts \\
\hline & 9003 & Artistic creation \\
\hline & 9004 & Operation of arts facilities \\
\hline & 9101 & Library and archives activities \\
\hline & 9102 & Museums activities \\
\hline & 9103 & Operation of historical sites and buildings and similar visitor attractions \\
\hline & 9104 & Botanical and zoological gardens and nature reserves activities \\
\hline & 9311 & Operation of sports facilities \\
\hline & 9312 & Activities of sports clubs \\
\hline & 9313 & Fitness facilities \\
\hline & 9319 & Other sports activities \\
\hline & 9321 & Activities of amusement parks and theme parks \\
\hline & 9329 & Other amusement and recreation activities \\
\hline
\end{tabular}


Based on the classifications made by Howkins [13], Florida [14] and The New England Council [15], was made a creative areas classification of the 66 NACE codes of the creative sector for Romania (Table 1.)

\section{GIS analysis}

Using QGIS 3.4, an open-source software, have been made maps for each year, for the period 2000-2016, for the value of number of employees, in a sequential color scheme, at the level of territorial administrative unit.

\section{Graphical models}

The graphical models show the evolution of the values of number of employees for the period between 2000-2016. The graphs show the evolution of the 7 classes (Publishing, Media and cinema, IT, Architecture and engineering, Education and research, Health and Culture and recreation) at national and regional level and also show the evolutions of the NACE codes that belong to the respective classes.

The values for turnover, for a better analysis, are expressed in the national currency (Lei), thus that at the course of the National Bank of Romania 1 euro represents 4.75 LEI.

\section{RESULTS}

The spatial dimension of the number of employees in the creative sector for the Bucharest-Ilfov Development Region (Fig. 2) shows an upward evolution during the analysis period. At the level of the region there are 3 cities that have the highest values of the number of employees, these being Bucharest with 39,618 employees at the level of 2000, Măgurele with 1,751 employees and Volunteers with 286 employees. For the years 2008-2009 the number of employees in the creative sector increased, thus having for 2008: 125,814 employees in Bucharest, 2,133 employees in Volunteers and 1,951 employees in Măgurele, in 2009 the number of employees in the creative sector increased (129,998 employees in Bucharest, 2,623 employees in Volunteers and 1,812 employees in Măgurele). In the last reference year of the study, the most important cities that add up a significant number of employees are Bucharest (115,945 employees), Volunteers (4156 employees) and Măgurele (2,058 employees).

The evolution of the number of employees for the Publishing area (Fig. 3) shows an upward trend (7,628 employees at national level and 3,721 employees at region level), with a maximum of the number of employees in 2008 (23,273 employees at Romania level and 12,683 employees at the level Development Region of Bucharest-Ilfov). The number of employees in this class decreases after 2008, due to the economic crisis, reaching a number of 20,303 employees at national level and 11,304 at the region level). The decrease in the number of employees stops in 2012 when the number of employees begins to increase reaching in 2016 to 18,080 (national) and 10,327 (regional).

The most important NACE codes for this class are 5829 - Other software publishing (with 6,085 employees), 5811 - Book publishing (1,682 employees) and 5814 - Publishing of journals and periodicals (with 1,110 employees in 2016) (Fig. 4). 


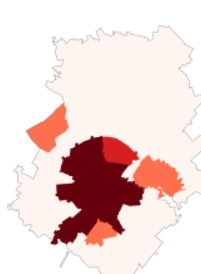

2000

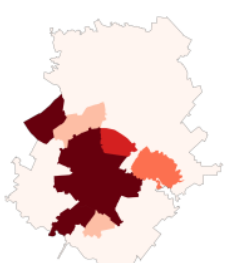

2003

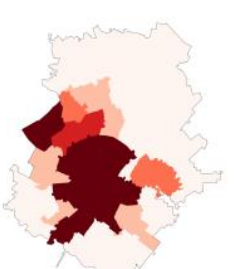

2006

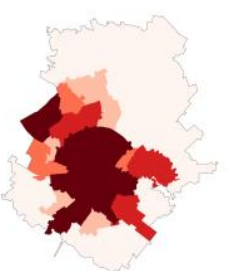

2009

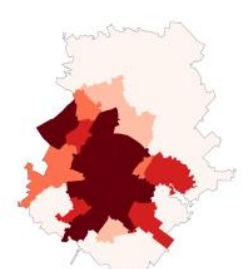

2012

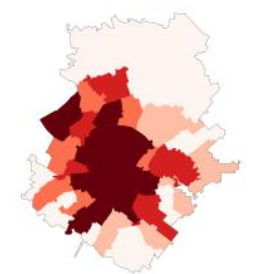

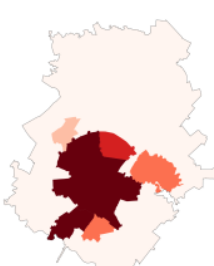

2001

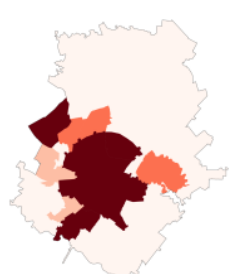

2004

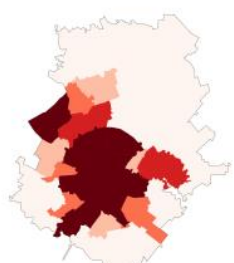

2007

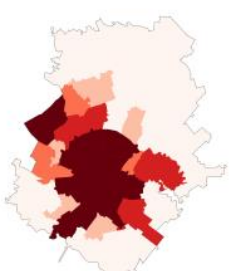

2010

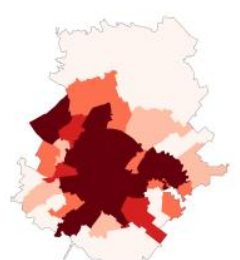

2013

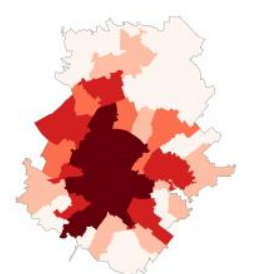

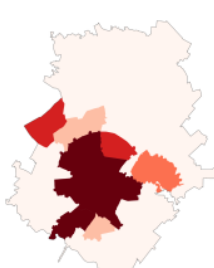

2002

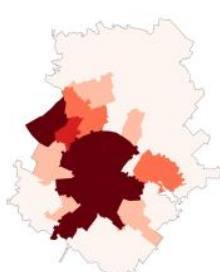

2005

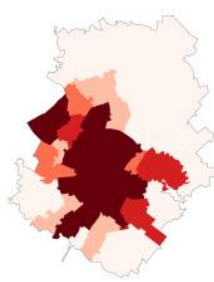

2008

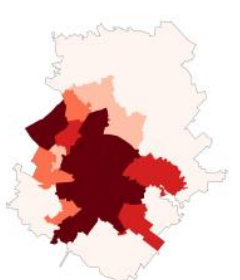

2011

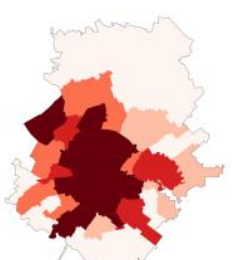

2014

Figure 2. Spatial distribution of the number of employees in the creative sector in theBucharest-Ilfov Development Region

Source: UB/1423 


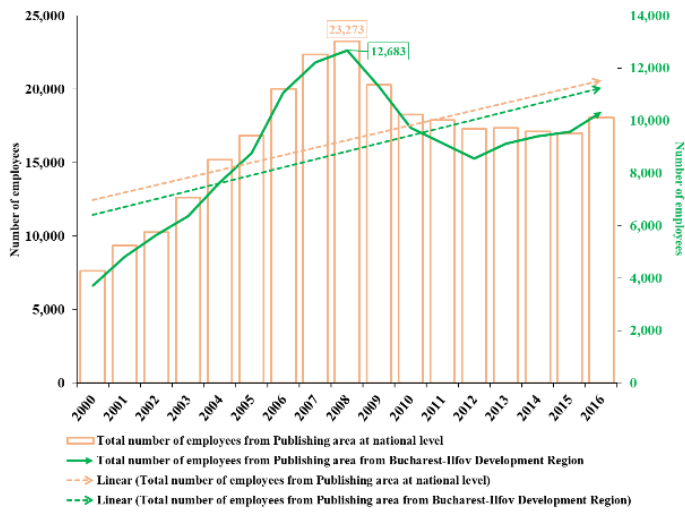

Figure 3. Evolution of the total number of employees for Publishing area

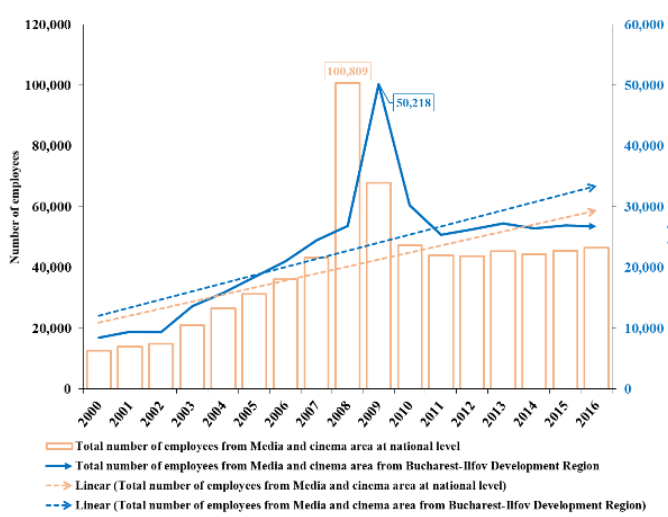

Figure 5. Evolution of the total number of employees for Media and cinema area

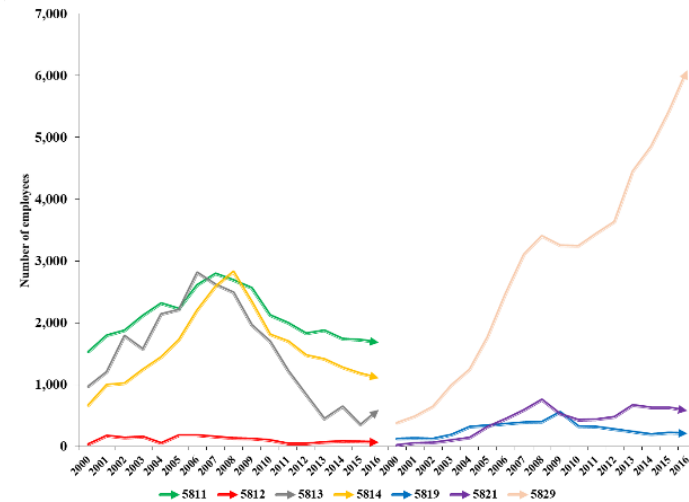

Figure 4. Evolution of the total number of employees for NACE codes belonging Publishing area

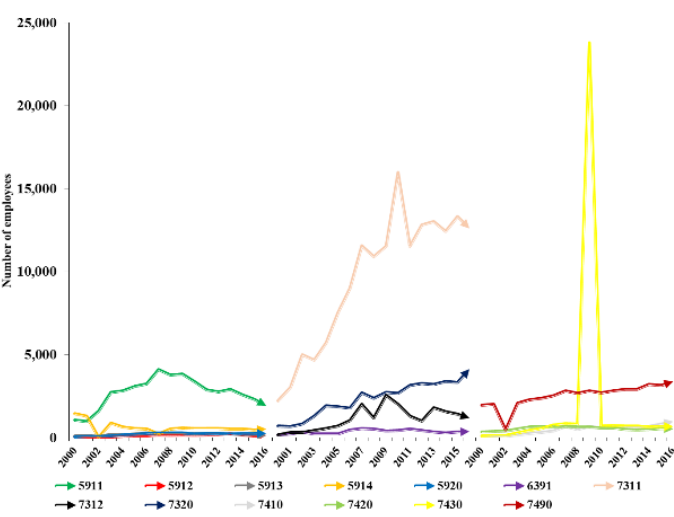

Figure 6. Evolution of the total number of employees for NACE codes belonging Media and cinema area Source: UB/1423

The number of employees for Media and cinema area (Fig. 5) amounted in the year 2000 to 12,684 employees (at national level) and 8,489 (at regional level). There is an evolution of values until 2009, followed by a decrease in the number of employees (in 2008 - 43,315 employees and 100,809 employees in 2009 at national level and 24,551 employees in 2008 and 26,858 employees in 2009 at regional level). After 2011, there is a stagnation of values, with a number of 46,504 employees (national) respectively, 26,784 employees at regional level.

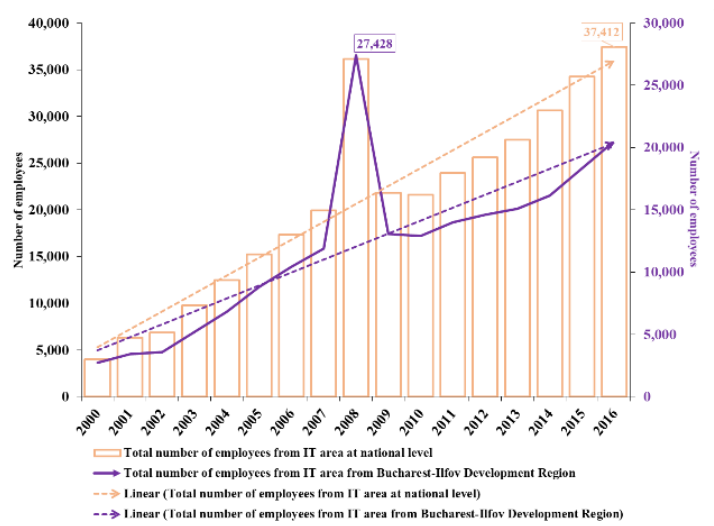

Figure 7. Evolution of the total number of employees for IT area

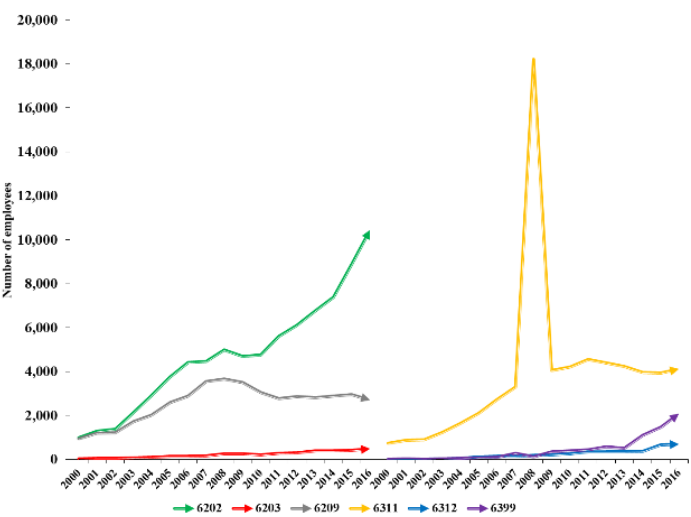

Figure 8. Evolution of the total number of employees for NACE codes belonging IT area 
This creative sector class has a total of 13 NACE codes (Fig. 6), which have a significant number of employees being 7311 - Advertising agencies (12,600 employees), 7320 Market research and public opinion polling (4,130 employees) and 7490 - Other professional, scientific and technical activities n.e.c. (3,375 employees).

The IT sector is well represented and presents an increasingly sought-after workforce. For IT area (Fig. 7) is represented an ascending route with a maximum of values in 2008 36,157 employees at national level and 27,428 employees at region level, the values decrease in 2009 due to the economic crisis reaching 21,829 employees at national level and 13,077 employees at region level. In 2016, the number of employees reaches 37,412 at the national level and at 20,541 at the regional level.

At the class level the most important 2 NACE codes are 6202 - Computer consultancy activities (10,451 employees) and 6311 - Data processing, hosting and related activities (4,109 employees) (Fig. 8).

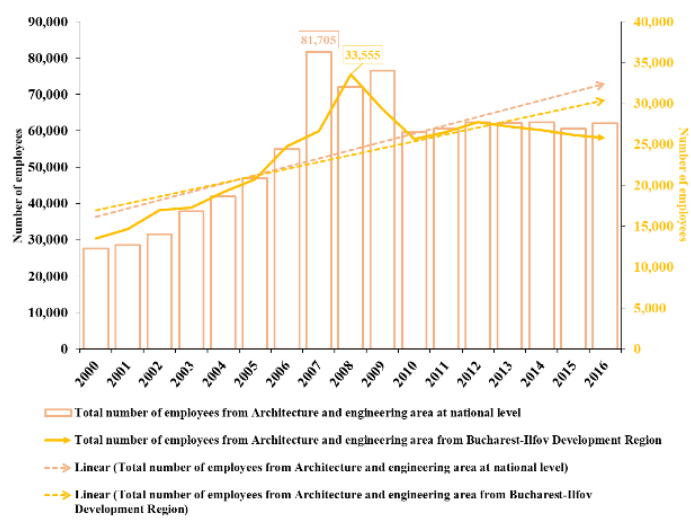

Figure 9. Evolution of the total number of employees for Architecture and engineering area

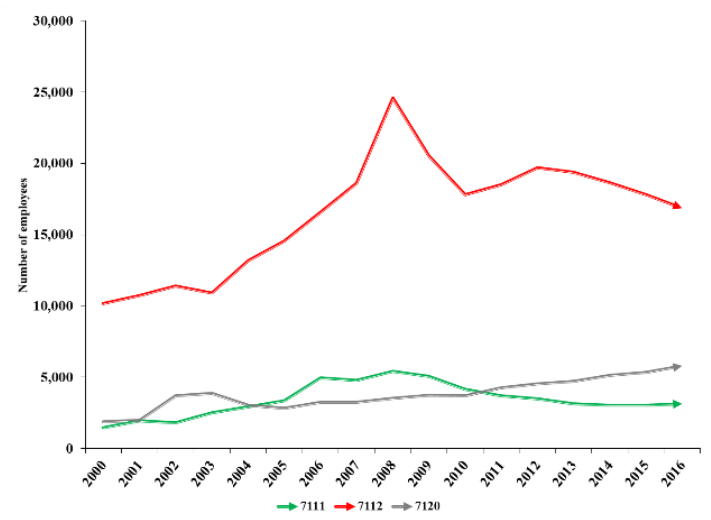

Figure 10. Evolution of the total number of employees for NACE codes belonging Architecture and engineering area

Source: UB/1423

The evolution of Architecture and engineering area (Fig. 9) shows an upward trend in the number of employees, with an increase until 2008 and a decrease due to the crisis for the number of employees at regional level, with values of 33,555 employees in 2008 and 29,333 employees in 2009. At national level after 2008, there is an increase in the number of employees (72,046 in 2008 and 76,578 in 2009). The values show a downward trend towards the end of the period.

This class adds up to 3 NACE codes, the one with a high contribution of employees being 7112 (24,606 employees in 2008, 20,546 in 2009 and 16,869 in 2016), showing a downward trend (Fig. 10). 


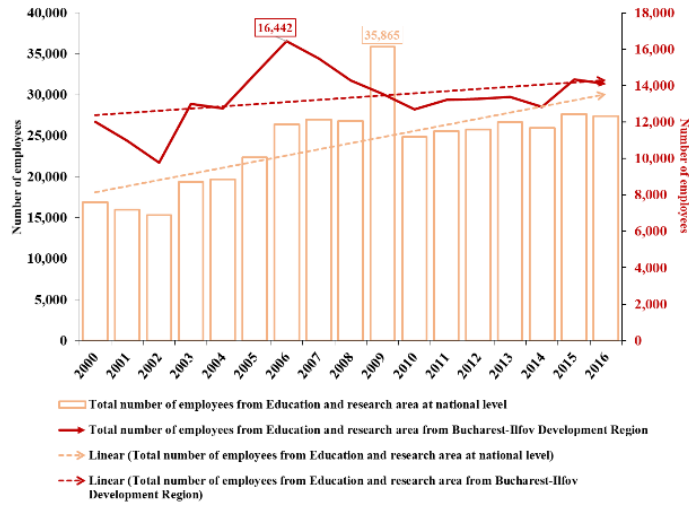

Figure 11. Evolution of the total number of employees for Education and research area

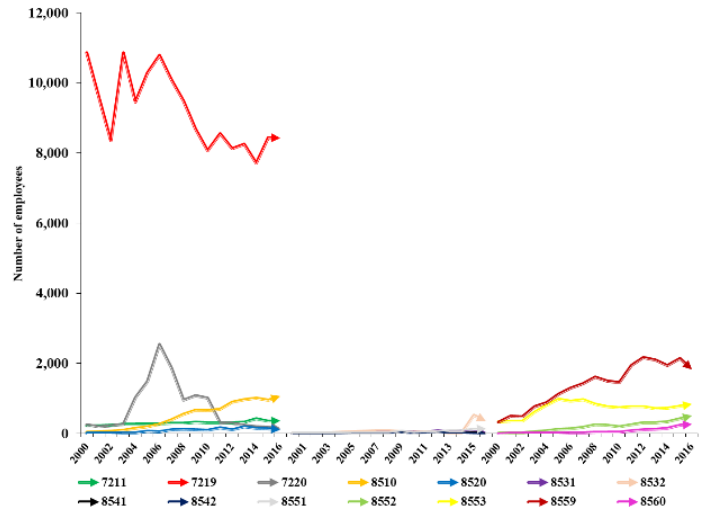

Figure 12. Evolution of the total number of employees for NACE codes belonging Education and research area

Source: UB/1423

The Education and research class (Fig. 11) shows a fluctuating trajectory of the total number of employees, with a number of 26,813 employees in 2008 and 35,865 in 2009 at national level and a number of 14,284 employees in 2008, respectively 13,553 in 2009. 2009 shows a stagnation of the number of employees with slight decreases towards the end of the analysis period (27,410 at national level and 14,090 at regional level).

Education and research area totals 14 NACE codes, the most significant values being held by code 7219 - Other research and experimental development on natural sciences and engineering (8,426 employees in 2016) (Fig. 12).

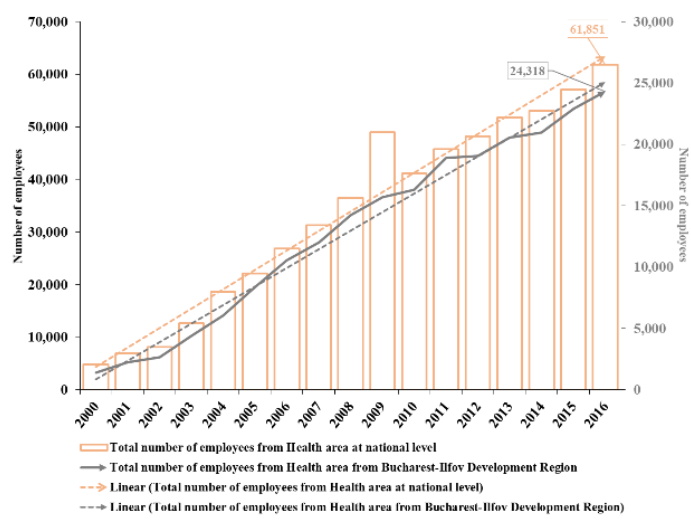

Figure 13. Evolution of the total number of employees for Health area

Source: UB/1423

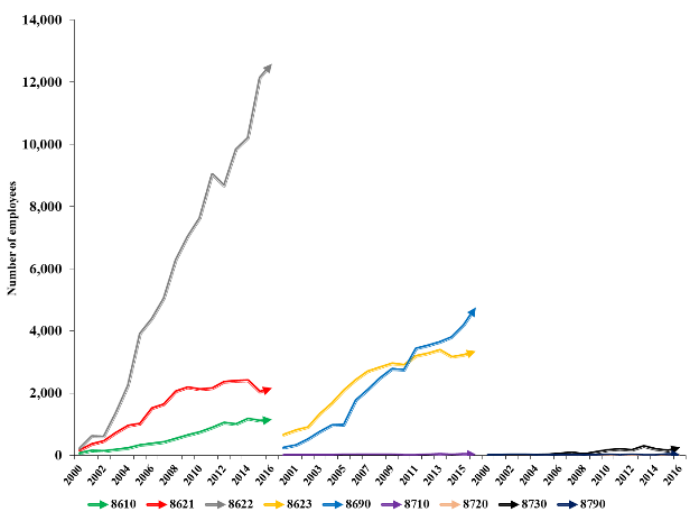

Figure 14. Evolution of the total number of employees for NACE codes belonging Health area

The total number of employees in the Health area shows a positive evolution, a constant growth without significant fluctuations. The economic crisis does not seem to affect this sector, due to the growth of the employees in 2009 (36,514 employees in 2008, 48,962 employees in 2009 at national level and 14,230 employees respectively, 15,713 employees in the region). The peaks are reached in 2016 when there are 61,851 employees at national level and 24,318 at regional level.

This class comprises 9 NACE codes belonging to the creative sector, of which the most significant contribution is 8622 - Specialist medical practice activities with a number of 12,577 employees in 2016 (Fig. 14). 


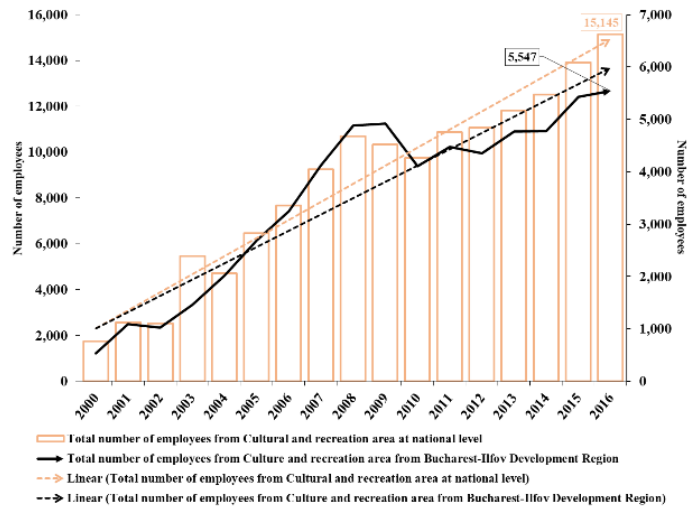

Figure 15. Evolution of the total number of employees for Culture and recreation area

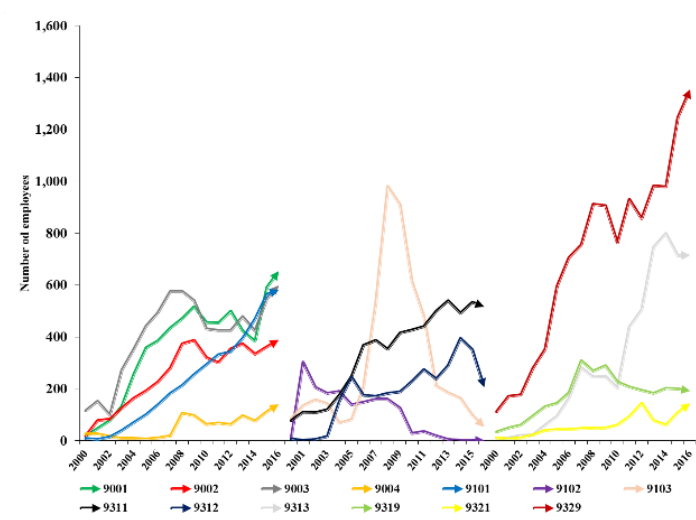

Figure 16. Evolution of the total number of employees for NACE codes belonging Culture and recreation area

Source: UB/1423

The evolution of the total number of employees in the Culture and recreation area (Fig. 15) in the Bucharest-Ilfov Development Region shows an increase in values until 2008, followed by a slight decrease and increases until the end of the analysis period. A total of 10,703 employees in 2008 and 10,322 employees in 2009 total the class at the national level and 4,883 respectively, 4,924 at the regional level. The maximum values are reached in 2016, 15,145 employees at national level and 5,547 at the region level.

The class has a total of 13 NACE codes, the sum of which is a large number of employees being 9329 - Other amusement and recreation activities (1,354 employees) (Fig. 16).

\section{CONCLUSIONS}

The structural analysis of the creative economies in the Bucharest-Ilfov Development Region highlights the particularities of the emerging spaces, structured around the big urban centers, where the creative economies have a general tendency of spectacular growth.

The analysis of the spatial dimension shows the concentration of the high values near the main road connections between the polarizing center, Bucharest, and the emerging system, the tendency of migration to the periphery being stronger after the economic crisis, statistically registered in 2009.

The behaviour of creative economies is a relevant indicator for evaluating the sustainable development of local economies, the connection between the complexity of local economies and the growth of creative economies being evident. Quantifying the complex links between the components of the territorial systems requires the development of the analysis methodologies, in many researches the imaginary ones bringing a significant increase of knowledge of the multiplication effects generated by the spectacular evolution of an economic component [16], [17], [18], [19], [20], [21], [22], [23], [24].

\section{Aknowledgement}

This paper is co-financed from the Human Capital Operational Program 2014-2020, project number POCU / 380/6/13/125245 no. 36482 / 23.05.2019 "Excellence in interdisciplinary $\mathrm{PhD}$ and post- $\mathrm{PhD}$ research, career alternatives through entrepreneurial initiative (EXCIA)", coordinator The Bucharest University of Economic Studies". 


\section{REFERENCES}

[1] Organization for Economic Cooperation and Development, Content as a newgrowth industry, Working Party on the Information Economy, Paris, 1998.

[2] Rifkin J. The Age of Access: How the Shift from Ownership to Access is Transforming Modern Life, 2000, Penguin, London In Bae S.H., Yoo K., Economic modeling of innovation in the creative industries and its implications, Technological Forecasting \& Social Change, vol. 96, pp 101-110, 2015.

[3] Howkins J. The Creative Economy: How People Make Money From Ideas, 2001, Allen Lane, London In Bae S.H., Yoo K., Economic modeling of innovation in the creative industries and its implications, Technological Forecasting \& Social Change, vol. 96, pp 101-110, 2015.

[4] Moraes J.L. Economia Criativa e Perspectivas de Desenvolvimento: Resgates de Celso Furtado, 2011 In Fachinelli A.C., Carrillo F.J., D'Arisbo A., Capital system, creative economy and knowledge city transformation: Insights from Bento Gonçalves, Brazil, Expert Systems with Applications, vol. 41, pp 5614-5624, 2014.

[5] Evans G. Creative cities, creative spaces and urban policy, Urban Studies, vol. 46, pp 10031040, 2009.

[6] United Nations, Creative Economy Report 2013, United Nations, Geneva and New York In Sung T.K. The creative economy in global competition, Technological Forecasting \& Social Change, vol. 96, pp 89-91, 2015.

[7] Lazzeretti L., Boix R., Capone F. Do creative industries cluster? Mapping Creative Local Production Systems in Italy and Spain, Departament d'Economia Aplicada, UAB.

[8] Boix R., Capone F., De Propris L., Lazzeretti L., Sanchez D. Comparing creative industries in Europe, European Urban and Regional Studies, vol. 23, 935-940, 2016.

[9] Grodach C., Currid-Halkett E., Foster N., Murdoch J. The location patterns of artistic clusters: A metro - and neighborhood-level analysis. Urban Studies, vol. 51, pp 2822-2843, 2014.

[10] Currid E. The Warhol economy: How fashion, art and music drive New York City, Publisher: NJ: Princeton University Press., Princeton, 2009.

[11] Currid E. Bohemia as subculture; "Bohemia" as industry: Art, culture and economic development. Journal of Planning Literature, vol. 23, pp 368-382, 2009.

[12] Markusen A., Gadwa A. Arts and culture in urban or regional planning: A review and research agenda. Journal of Planning Education and Research, vol. 29, pp 379-391, 2010.

[13] Howkins J. The Creative Economy: How People Make Money From Ideas, Allen Lane/Penguin Press, 2001.

[14] Florida R. L. The Rise of the Creative Class: And How It's Transforming Work, Leisure, Community and Everyday Life. New York, NY: Basic Books, 2002.

[15] The New England Council, 2000, The Creative Economy Initiative: The Role of the Arts and Culture in New England's Economic Competitiveness.

[16] Prăvălie R., Sirrodoev I., Patriche C. V., Bandoc G., \& Peptenatu D. The analysis of the relationship between climatic water deficit and corn agricultural productivity in the Dobrogea plateau, Carpathian Journal of Earth and Environmental Sciences, vol. 9, pp 201-2014, 2014.

[17] Pintilii R.D., Andronache I., Simion A.G., Drăghici C.C., Peptenatu D., Ciobotaru A.M., Dobrea R.C. \& Papuc R.M. Determining forest fund evolution by fractal analysis (SuceavaRomania), Urbanism Architecture Constructions, vol. 7, pp 31-42, 2016.

[18] Pintilii R.D., Andronache I., Diaconu D.C., Dobrea R.C., Zelenakova M., Fensholt R., Peptenatu D., Draghici C.C. \& Ciobotaru A.M. Using Fractal Analysis in Modeling the Dynamics of Forest Areas and Economic Impact Assessment: Maramures County, Romania, as a Case Study, Forests, vol. 8, 2017. 
[19] Pintilii R.D., Peptenatu D., Draghici C., Irina S., Stoian R.D., Structural Changes in The Entrepreneurial Profile of The Creative Industries in Romania, 2nd Global Conference on Business, Economics, Management and Tourism, Edited by:Iacob, AI, Procedia Economics and Finance, Vol. 23, pp: 1147-1151, 2015.

[20] Prăvălie R., Patriche C.V., Sîrodoev I., Bandoc G., Dumitrașcu M. \& Peptenatu D. Water deficit and corn productivity during the post-socialist period. Case study: Southern Oltenia drylands, Romania, Arid Land Research and Management, vol. 30, pp 239-257, 2016.

[21] Andronache I., Fensholt R., Ahammer H., Ciobotaru A.M., Pintilii R.D., Peptenatu D., Drăghici C.C., Diaconu D. C., Radulovic M., Pulighe G., Azihou A.F., Toyi M.S. \& Sinsin B. Assessment of Textural Differentiations in Forest Resources in Romania Using Fractal Analysis, Forests, vol. 8, 2017.

[22] Drăghici C.C., Andronache I., Ahammer H., Peptenatu D., Pintilii R.D., Ciobotaru A.M., Simion A.G., Dobrea R.C., Diaconu D.C., Vişan M.C., Papuc R.M. Spatial evolution of forest areas in the northern Carpathian Mountains of Romania, Acta Montanistica Slovaca, vol. 22, pp 95-106, 2017.

[23] Gruia A.K., Dobrea R.C., Simion C.P., Dima C., Grecu A., Hudea O.S., Marin M., Andronache I., Peptenatu D. The Use of Sholl and Kolmogorov Complexity Analysis in Researching on the Sustainable Development of Creative Economies in the Development Region of Bucharest-Ilfov, Romania, Sustainability, vol. 11, 6195, 2019. DOI: doi:10.3390/su11226195

[24] Grecu A., Gruia A.K., Marin M., Bănuță M., Olteanu C., Constantin I., Gadoiu M., Teodorescu C., Dobrea R.C., Drăghici C.C., Specificity of Sustainable Structural Dynamics of Local Economy in Romanian Tourist Resorts, Sustainability, vol. 11, 7155, 2019. DOI: doi:10.3390/su11247155 